\title{
Dynamics of Arachidonic Acid Mobilization by Inflammatory Cells
}

Alma M. Astudillo, David Balgoma, María A. Balboa, and Jesús Balsinde*

Instituto de Biología y Genética Molecular, Consejo Superior de Investigaciones Científicas (CSIC), 47003 Valladolid, Spain, and

Centro de Investigación Biomédica en Red de Diabetes y Enfermedades Metabólicas Asociadas (CIBERDEM), 08036 Barcelona, Spain

*Corresponding author. Phone, +34-983-423-062; Fax, +34-983-184-800;

e-mail: jbalsinde@ibgm.uva.es

Keywords: Arachidonic Acid; Phospholipid Remodeling; Eicosanoid Metabolism; Lipidomics; Mass Spectrometry.

Running Title: AA Mobilization in Inflammatory Cells 


\section{Abstract}

The development of mass spectrometry-based techniques is opening new insights into the understanding of arachidonic acid (AA) metabolism. AA incorporation, remodeling and release are collectively controlled by acyltransferases, phospholipases and transacylases that exquisitely regulate the distribution of AA between the different glycerophospholipid species and its mobilization during cellular stimulation. Traditionally, studies involving phospholipid AA metabolism were conducted by using radioactive precursors and scintillation counting from thin layer chromatography separations, that provided only information about lipid classes. Today, the input of lipidomic approaches offers the possibility of characterizing and quantifying specific molecular species with great accuracy and within a biological context associated to protein and/or gene expression in a temporal frame. This review summarizes recent results applying mass spectrometrybased lipidomics approaches to the identification of AA-containing glycerophospholipids, phospholipid AA remodeling and synthesis of oxygenated metabolites.

Abbreviations: AA, arachidonic acid; $\mathrm{PLA}_{2}$, phospholipase $\mathrm{A}_{2} ; \mathrm{CPLA}_{2} \alpha$, group IVA cytosolic PLA 2 ; iPLA $2, \mathrm{Ca}^{2+}$-independent $\mathrm{PLA}_{2} ;$ sPLA 2 , secreted PLA 2 ; CoA-IT, CoAindependent transacylase; ACS, acyl-CoA synthetase; ESI, electrospray ionization; HPLC, high performance liquid chromatography; MS, mass spectrometry; TLC, thin layer chromatography; PC, choline glycerophospholipids; PE, ethanolamine glycerophospholipids; PI, phosphatidylinositol. 


\section{Introduction}

The traditional view of lipids typically acting as membrane building blocks or fuel has changed dramatically in recent years. Now, it is widely accepted that these biomolecules are centrally involved in cell signaling, and that imbalances in lipid metabolism are causative agents of a number of high-prevalence disorders, ranging from cardiovascular disease, diabetes and obesity to cancer [1-3]. Hundreds to thousands of lipid species can be identified in a given biological system at a cell or tissue levels, each of them with a particular distribution and function [4].

The significant advances in analytical techniques over the last years, especially mass spectrometry (MS) and the parallel improvement in molecular ionization, together with the possibility to use this technique as a detector in chromatographic separation, have constituted a breakthrough in lipid analysis and, therefore, a better understanding of lipid biochemistry has been possible. This has contributed to the development of lipidomics [5-7], a branch of metabolomics that pursues a thorough scientific study of lipids. Lipidomics not only aims at characterizing and analyzing lipid species in a particular state of the cell — called the static composition-, but also aims at integrating the understanding of lipid pathways (synthesis, remodeling or transport) with their biological roles and with gene regulation and protein expression $[5,7-11]$.

There are two major strategies for lipidomic analysis. The first one, called global lipidomics, pursues the analysis of the whole lipidome of biological samples, by using either direct infusion methods or previous liquid chromatography steps. On the other hand, targeted or focused lipidomics, is based on setting conditions for analysis of specific categories of lipids, thus improving sensitivity [11-14]. 
As lipidomics is focused on profiling the static composition of molecular species in biological samples, the term metabolipidomics has been coined to emphasize the dynamical aspects of lipids in cells, organs, tissues and whole organisms [15]. In this case, lipids containing stable isotopes are used to follow their metabolic fate through the various possible pathways, thus facilitating the identification of minor species with rapid turnover rates.

\section{Cellular Utilization of Arachidonic Acid}

Arachidonic acid $(5,8,11,14$-eicosatetraenoic acid) is an $\omega-6$ essential fatty acid, obtained directly from diet or, alternatively, synthesized from linoleic acid (18:2n-6) through the successive actions of $\Delta 6$-desaturase, elongase and $\Delta 5$-desaturase, that occurs mainly in liver but also in other tissues (Figure 1). In western diets it is calculated that the intake of AA is $0.2-0.3 \mathrm{~g} /$ day, whereas the intake of linoleic acid is $10-20 \mathrm{~g} /$ day, indicating that the amount of AA coming from linoleic acid is higher than that coming directly from the diet $[16,17]$.

AA is the common precursor of the eicosanoids, a family of lipid mediators with key roles in physiology and pathophysiology, particularly in inflammatory reactions $[18$, 19], although the fatty acid can exert potent biological roles by itself, e.g. by inducing apoptosis [20-22]. Additionally, when present in elevated concentrations, AA can give rise to significant quantities of its 2-carbon elongation product, adrenic acid (22:4n-6). Adrenic acid is the precursor of 22-carbon 1a,1b-dihomologue prostaglandins (dihomoprostaglandins) [23-26]. The potent biological activity of the eicosanoids 
compels the cells to tightly control the leveles of free AA in such a manner that availability of free AA is frequently a rate-limiting step in eicosanoid generation [27, 28].

In inflammatory cells, AA is generally found esterified in the sn-2 position of glycerophospholipids, particularly choline glycerophospholipids (PC), ethanolamine glycerophospholipids (PE), and phosphatidylinositol (PI) [28]. Cellular free AA levels are controlled by two competing reactions; on one hand, the phospholipase $\mathrm{A}_{2}\left(\mathrm{PLA}_{2}\right)$ mediated cleavage of the $s n-2$ position of phospholipids to yield the free fatty acid and, on the other, the CoA-dependent acyltransferase-modulated acylation reactions that reincorporate the free fatty acid into phospholipids $[29,30]$. In resting unstimulated cells, the reacylation reactions dominate over the $\mathrm{PLA}_{2}$-mediated deacylation step; thus free AA is kept at very low levels. Stimulation of the cells by receptor agonists results in the activation of intracellular $\mathrm{PLA}_{2} \mathrm{~s}$ [31-35]. Under these conditions, the rate of AA release clearly exceeds that of reincorporation into phospholipids; hence, net accumulation of free AA occurs that is followed by its conversion into various eicosanoids. Nevertheless, AA reacylation reactions are still very significant under stimulated conditions, as manifested by the fact that only a minor fraction of the free AA released by $\mathrm{PLA}_{2} \mathrm{~S}$ is converted into eicosanoids, the remainder being effectively incorporated back into phospholipids [36, 37].

The first step for AA incorporation into cellular lipids is the activation of the carboxyl group of the fatty acid by thioesterification with CoA. This reaction is catalyzed by acyl-CoA synthetases, of which there are many in cells [30]. In the context of AA metabolism it is worth mentioning the long chain acyl-CoA synthetases ACSL3, 4 and 6, as they show some selectivity towards AA [38-40]. The next step in the AA incorporation 
is the esterification of the fatty acid into primarily the sn-2 position of glycerophospholipids, a reaction that is carried out by lysophospholipid:acyl CoA acyltransferases, in particular those of the membrane-bound O-acyltransferase family (MBOAT) [41]. Those that have been found to exhibit clear preference for AA include lysoPC:acyl-CoA acyltransferase 2 [42], lysoPC:acyl-CoA acyltransferase 3 [43-45], LysoPI:acyl-CoA acyltransferase and lysophosphatidic acid:acyl-CoA acyltransferase 3 $[44,46,47]$. In addition, the lipase CGI-58 shows lysophosphatidic:acyl-CoA acyltransferase with high preference towards AA [48]. For detailed information on the biochemistry and functioning of CoA-dependent acyl transferases, the reader is kindly referred to recent reviews on the subject [30, 49-51].

AA bound to phospholipid is also the subject of successive transacylation reactions aimed at ensuring the proper distribution of the fatty acid within the various cellular phospholipid pools $[29,30,52-54]$. This appears to be important not only for membrane homeostasis but also for the execution of appropriate cell responses during physiological and pathophysiological activation [55-59]. These transacylation reactions are catalyzed by CoA-independent transacylase (CoA-IT), an enzyme that transfers AA moieties preferentially from diacyl PC species to PE plasmalogens [29, 30] (Figure 1). The sequence of CoA-IT is yet to be described. Thus, currently the only manner to study the cell regulation of CoA-IT is by following its enzyme activity [60, 61].

Once the AA has been effectively incorporated into phospholipids the fatty acid can be eventually liberated, especially under cell stimulation conditions, by a number of $\mathrm{PLA}_{2}$ enzymes. So far, more than 30 enzymes possessing PLA $\mathrm{P}_{2}$ activity have been described in mammals [62-64]. Attending to sequence homology criteria, the $\mathrm{PLA}_{2} \mathrm{~s}$ have 
been classified into 16 groups [62-65], although based on biochemical features they can be grouped into 5 main families, namely the $\mathrm{Ca}^{2+}$-dependent secreted $\mathrm{PLA}_{2} \mathrm{~s}\left(\mathrm{sPLA}_{2}\right)$, $\mathrm{Ca}^{2+}$-dependent cytosolic $\mathrm{PLA}_{2} \mathrm{~S}\left(\mathrm{cPLA}_{2}\right), \mathrm{Ca}^{2+}$-independent cytosolic $\mathrm{PLA}_{2} \mathrm{~S}\left(\mathrm{iPLA}_{2}\right)$, platelet-activating factor acetylhydrolases, and lysosomal PLA $_{2}$ s. Of these, the first two have been repeatedly implicated in receptor-mediated AA mobilization in response to a variety of stimuli. Today, it is firmly established that the calcium-dependent cytosolic group IVA PLA $\mathrm{P}_{2} \alpha\left(\mathrm{cPLA}_{2} \alpha\right)$ is the critical enzyme in stimulus-dependent AA mobilization and that, depending on cell type and stimulation conditions, a sPLA $\mathrm{PLay}_{2}$ also participate by amplifying the $\mathrm{cPLA}_{2} \alpha$-regulated response [66-91]. Under some conditions, the $\mathrm{Ca}^{2+}$-independent group VIA iPLA 2 may also effect the AA release [9294] but in other conditions, it mediates phospholipid reacylation reactions by regulating the steady-state level of lysoPC [95-97], reflecting the multiplicity of functions that this enzyme appears to serve depending on cell type [34, 98]. For detailed information on the cellular regulation of AA mobilization by $\mathrm{PLA}_{2}$ enzymes, the reader is kindly referred to the many comprehensive reviews that have been published in recent years covering different aspects of the subject [31-35, 51, 62-65, 99-104].

After the AA has been released from phospholipids under stimulation conditions, it can be metabolized into eicosanoids through four different pathways, namely cyclooxygenase, lipoxygenase, cytochrome-P450 and oxygen species-triggered reactions (Figure 2). These pathways yield a plethora of compounds, such as prostaglandins, isoprostanes, thromboxane, leukotrienes, lipoxins and epoxyeicosatrienoic acids, all of which act in a paracrine/autocrine manner through specific receptors on the plasma membrane. 
For the biosynthesis of prostaglandins and tromboxane from AA, synthesis of $\mathrm{PGH}_{2}$ via cyclooxygenase is the first step. Cyclooxygenase incorporates molecular $\mathrm{O}_{2}$ and forms $\mathrm{PGG}_{2}$ that is subsequently reduced to form $\mathrm{PGH}_{2}$ by the action of the peroxidase active site. $\mathrm{PGH}_{2}$ is the substrate of different prostaglandin and thromboxane synthases that are expressed in tissues and cells in a selective-manner and lead to the formation of $\mathrm{PGE}_{2}, \mathrm{PGD}_{2}, \mathrm{PGI}_{2}, \mathrm{PGF}_{2} \alpha$ and $\mathrm{TXA}_{2}$ [105]. These compounds exert important biological functions, i.e. modulating smooth muscle tone, vascular permeability, hyperalgesia, fever and platelet aggregation [106].

Leukotrienes, eoxins, lipoxins, and hydroperoxyeicosatetranoic acids (HPETEs) are synthesized from AA by lipoxygenase enzymes (5-, 12- and 15-lipoxygenase) that add molecular $\mathrm{O}_{2}$ into AA stereospecifically. 5-Lipoxygenase forms 5hydroperoxyeicosatetraenoic acid (5-HPETE) that is metabolized to $\mathrm{LTA}_{4}$ in a second step. $\mathrm{LTA}_{4}$ is unstable, and can rapidly be converted to $\mathrm{LTB}_{4}$, a potent chemoattractant for polymorphonuclear leukocytes. Additionally, $\mathrm{LTA}_{4}$ can be converted to $\mathrm{LTC}_{4}$ which is the precursor of $\mathrm{LTD}_{4}$ and $\mathrm{LTE}_{4}$. These three leukotrienes constitute the slow-reacting substances of anaphylaxis that act in the allergic response [107]. Eoxins are produced in a similar manner as the leukotriens, but by the action of 15-lipoxygenase, and are almost as potent as 5-lipoxygenase-derived leukotrienes [108]. Lipoxins are generated by transcellular biosynthesis and have anti-inflammatory and resolving roles [109].

Other metabolites, including epoxyeicosatrienoic acids (EETs) and their products from epoxy-ring hydrolysis, dihydroxyeicosatrienoic acids (DHETs), are derived from cytochrome-P450 enzymes [110]. EETs have been associated with anti-inflamatory properties in cardiovascular diseases [111]. 
The fourth pathway of production of eicosanoids is the reaction of AA with reactive oxygen species to yield a group of compounds known as isoprostanes. As radical-driven reactions are not stereo-selective, they generate different isomers with structures similar to those of prostaglandins. Because of their origin, isoprostanes have been used as markers of oxidative stress [112].

\section{Lipidomic Studies of Cellular Arachidonate Metabolism}

Traditionally, cellular studies on AA movement to and from glycerophospholipids made extensive use of radiolabeled fatty acid. After lipid extraction and chromatographic separation, quantification was carried out by scintillation counting [54-59, 66-76, 113119]. Studies carried out in the 80 's and early 90 's using this general strategy demonstrated that most of the AA incorporated into cellular phospholipids resides in PC, PE or PI, that the major AA-containing phospholipid classes in many cell types, especially those involved in innate immunity and inflammation reactions-, usually contain ether linkages at the sn-1 position, and that major remodeling reactions involving AA occur between PC (primarily diacyl) species and PE (primarily alkenyl) species [29, 54-56,120-124]. However, a potential problem with the use of radioactive tracers is that sometimes, experiments are not carried out under equilibrium labeling conditions and, therefore, changes detected involve only discrete pools with higher turnover rates. Moreover, using this methodology, it is not possible to ascertain the exact molecular composition of the phospholipids to which AA is bonded.

The advent of HPLC coupled to MS, or direct infusion MS, has made it routinely 
possible to collect structure information, thus greatly strenghtening our knowledge on the cellular dynamics of AA. [12-14, 125-140]. Moreover, by using a metabolipidomic approach (i.e. combining the power of MS with use of stable isotopes such as deuteriumlabeled AA), dynamic information can also be obtained as to the differential mobilization of various cellular AA pools under defined stimulation conditions, thus allowing the understanding of lipid turnover in contrast with static measures under equilibrium conditions $[15,141]$.

Identification of the phospholipid acyl chains as well as their positioning in the sn-1 versus the sn-2 position of the glycerol backbone can be obtained through fragmentation experiments (ESI-MS/MS). Such assignments are usually straightforward for analyses of AA-containing PE and PI in the negative ion mode. Analysis of AAcontaining PC species is usually carried out in negative mode with postcolumn addition of acetic acid, as $\left[\mathrm{M}+\mathrm{CH}_{3} \mathrm{CO}_{2}\right]^{-}$adducts $[14,127,132,136-138,140]$.

Using $\left[{ }^{2} \mathrm{H}\right]_{8} \mathrm{AA}$ and reverse phase-HPLC-ESI-MS, Balgoma et al. [142] identified the PI molecular species that initially incorporate AA in human U937 promonocyte-like cells and peripheral blood monocytes. The unusual species $\mathrm{PI}\left(\left[{ }^{2} \mathrm{H}\right] \mathrm{AA} /\left[{ }^{2} \mathrm{H}\right] \mathrm{AA}\right)$ was found to behave as a major but short-lived acceptor of the AA, and its route of biosynthesis was described to involve the direct acylation of both the sn-1 and sn-2 positions of PI. Likewise, similar studies on the initial incorporation of AA into PE species revealed a fundamental difference between human U937 promonocytes and peripheral blood monocytes in that the former, but not the later, incorporate large quantities into various PE molecular species at short times [61]. This difference is attributed to the higher remodeling rate of U937 cells compared to monocytes, which in 
turn appears to be related to the intrinsically low AA content that these cells exhibit [61].

Rouzer et al. [143] compared the fatty acid remodeling of murine residential peritoneal macrophages and RAW 264.7 macrophage-like cells after exposure to yeastderived zymosan. Using tandem MS, AA deficiency of cultured cells compared with their primary counterparts was confirmed, as was the different distribution of AA among phospholipids in AA-enriched RAW 264.7 cells and peritoneal macrophages [143]. These data are relevant in that they emphasize the potential pitfalls of using AA-deficient cells by long term culture in studies of AA metabolism. Although this kind of studies have been useful to describe biochemical pathways, they have not always produced meaningful data from a physiological point of view, i.e. when compared with primary cells, since the AA deficiency of cultured cells usually results in much lower amounts of AA mobilized -and hence of eicosanoids produced-, and probably also the preferential use of AA phospholipid pools with higher turnover rates [74, 143].

In subsequent studies, Rouzer et al. [144] reported that the bulk of $\operatorname{cPLA}_{2} \alpha-$ mediated AA release in zymosan-stimulated macrophages arises from AA-containing PC species whereas AA-containing PE species show little or no changes. Similar to these studies, using reverse phase HPLC-ESI-MS, Balgoma et al. [145] described that all major AA-containing PC and PI species decrease in a cPLA ${ }_{2} \alpha$-dependent manner in zymosanstimulated human monocytes, with only minor changes in the levels of AA-containing PE species. Taking into account previous work utilizing $\left[{ }^{3} \mathrm{H}\right] \mathrm{AA}-\mathrm{labeled}$ cells under equilibrium labeling conditions [55-58], it seems likely that PE molecules also serve as immediate substrates for stimulus-induced AA mobilization in monocytes/macrophages, but these are rapidly reacylated using AA from other sources, e.g. PC, via CoA-IT- 
mediated reactions $[144,145]$. In this regard, a previous lipidomic study with human platelets demonstrated that ethanolamine plasmalogen species constituted by far the major sources of AA mobilized after thrombin stimulation of the cells at very short times, i.e. $90 \mathrm{~s}$ [146]. Collectively, these studies highlight a key distinctive advantage of applying an ESI-MS lipidomics approach to the analysis of AA metabolism, that is, the possibility of identifying the specific molecular species of phospholipids that act as donors and acceptors of AA moieties during activation. Thus, conclusions can now be drawn on the molecular specificity of the phospholipid substrate and the phospholipidhydrolyzing phospholipase(s) involved.

In the above-mentioned studies with human monocytes [145], the levels of the two minor species PI(20:4/20:4) and PC(20:4/20:4) were found to increase in zymosanactivated cells compared with resting cells, and a third species not present in resting cells, $\operatorname{PE}(16: 1 / 20: 4)$, appeared under stimulation conditions [145]. Analysis of the pathways involved in the synthesis of these three lipids indicated that $\operatorname{PI}(20: 4 / 20: 4)$ and PC(20:4/20:4) were produced in a deacylation/reacylation pathway via cPLA $2 \alpha$ and acylCoA synthetase-dependent reactions, whereas $\mathrm{PE}(16: 1 / 20: 4)$ was generated via a CoAindependent transacylation reaction [145]. The finding that certain AA-containing species that are detected at low levels or not detected at all under resting conditions, significantly increase in activated cells via selected biosynthetic pathways suggests that they may be regarded as lipid markers of particular activation states of the cells.

Lipidomic profiling of AA-containing phospholipids may also be useful to define cell-specific differences. Figure 3 compares the distribution of AA-containing phospholipids in human peripheral blood monocytes [145], human monocyte-derived 
macrophages [147], and mouse peritoneal macrophages [148], all obtained by reverse phase HPLC-ESI-MS under identical experimental conditions. Although the overall distribution of AA between glycerophospholipids is similar in the three cell types, some potentially useful differences are apparent. For example, the plasmalogen species $\mathrm{PC}(\mathrm{P}-16: 0 / 20: 4)$ is present at low levels in human monocytes and mouse macrophages but is by far the major AA-containing PC species of human macrophages. Similarly, $\mathrm{PC}(16: 0 / 20: 4)$ is present in trace amounts in human monocytes and macrophages but is one of the most abundant AA-containing PC species of mouse macrophages (Figure 3). As for human monocytes, note the conspicuous absence of the plasmalogen species PE(P-18:1/20:4) and $\mathrm{PE}(\mathrm{P}-18: 2 / 20: 4)$, which is counteracted by the high level of the related species $\mathrm{PE}(\mathrm{P}-18: 0 / 20: 4)$, compared to human and mouse macrophages.

Although not focusing directly on AA-containing phospholipids, other lipidomic studies looking for biomarkers in various macrophage cell types, have led to the identification of unusual glycerophospholipids such as ether-linked PI species, PE species containing very long fatty acyl chains, or phospholipids containing threonine as the polar headgroup [149]. Very recently, combining HPLC-ion trap MS and HPLC-triple quadrupole MS, Yang et al. [150] described changes in glycerophospholipid species in response to different levels of oxidative stress induced by $\mathrm{H}_{2} \mathrm{O}_{2}$ in EA.hy926 cells. In these studies, the authors identified 7 lysophospholipid correlating with $\mathrm{CPLA}_{2} \alpha$ activation under these conditions, which could potentially be regarded as biomarkers of oxidative stress conditions [150].

More ambitious lipidomic analyses have aimed at establishing the dynamics of lipid metabolism and regulation during inflammatory stimulation. Dennis et al. [151] 
carried out the first quantitative approach for the characterization of the whole lipidome of an inflammatory cell. Dynamic quantitative MS analyses were carried out, together with transcriptional measurements of genes involved in lipid metabolism in RAW 264.7 macrophage-like cells stimulated with $\mathrm{Kdo}_{2}$-lipid A, or treated with the pharmacological inhibitor compactin. This work focused on 400 lipid species from all major lipid classes, including fatty acids, acyl-CoAs, eicosanoids, glycerophospholipids, sphingolipids, sterols and glycerolipids [151]. In cells stimulated with the specific TLR4 agonist Kdo2lipid A, a good correlation was observed between expression of genes coding for enzymes of lipid metabolism and changes of the corresponding metabolites. However a potential shortcoming is that this information could be misleading if the regulation of enzyme levels is post-transcriptional, as is the case of e.g. $\mathrm{cPLA}_{2} \alpha$ [151]. Increases in cholesterol, lanosterol and desmosterol were also documented, as well as increases in sphingolipid content, consistent with induction of the de novo biosynthesis of sphingolipids. Finally, significant changes in phosphatidic acid and PI species were detected, with increases of saturated and monounsaturated phosphatidic acid species, and decreases of polyunsaturated species such as $\mathrm{PI}(38: 4)$-probably $\mathrm{PI}(18: 0 / 20: 4)-$ at $24 \mathrm{~h}$, raising the possibility that lipid molecules involved in signaling still act beyond $24 \mathrm{~h}$ stimulation [151].

The application of MS techniques for eicosanoid quantitation has supposed a significant breakthrough in this field of research, since traditional analyses, based in enzyme-linked immunosorbent assays (ELISA) allow the analysis of only one eicosanoid per assay, thus prohibiting great-scale assays. By using a lipidomic approach, Norris et al. [152] analyzed the eicosanoid profile together with protein and gene expression of 
enzymes of eicosanoid metabolism when different types of macrophages -murine residential peritoneal macrophages, bone marrow-derived macrophages, thioglycollate elicited macrophages and RAW 264.7 macrophage-like cells- were exposed to Kdo - $^{-}$ lipid A. Over 140 species were detected, including AA-derived metabolites generated by COX, LOX and CYP450 pathways (Figure 2) and those derived from non-enzymatic pathways. Lower levels of $\omega-3$ fatty acid-derived protectins and resolvins were also detected. In addition, adrenic acid-derived dihomoprostaglandins [23-25] were detected in all macrophage types, suggesting that these compounds may possess biological significance. Overall, the data confirmed that although there are potentially many factors that affect eicosanoid production such $\mathrm{PLA}_{2}$ activation, the enzymes of the AA reacylation pathway (Figure 1), and terminal synthases, the delayed phase of prostaglandin production by all macrophage types was strikingly dependent on the maximal level of COX-2 expression [152].

Andreyev et al. [153] focused their lipidomic analyses on the different subcellular localization of lipid species in RAW 264.7 cells, analyzing a total of 229 species in various compartments such as endoplasmic reticulum, mitochondria, nuclei, plasmalemma and cytoplasm, and addressing the changes occurring upon activation with $\mathrm{Kdo}_{2}$-lipid A. Cell activation led to remodeling of the lipidome in all subcellular compartments, apparently in an organelle-specific manner. Changes detected included increases in phosphatidic acid in the endoplasmic reticulum -suggestive of phospholipase $\mathrm{D}$ activation in that compartment- or increases in highly unsaturated cardiolipins and oxidized sterols in mitochondria -suggestive of oxidative stress in this organelle-. In addition, ether-linked phospholipids increased in plasma membrane but decreased in the 
endoplasmic reticulum under stimulation conditions, especially the ether species PE(P38:4/O-38:5), which probably contains AA [153].

\section{Concluding Remarks and Future Perspectives}

The robustness and sensitivity of mass spectrometry converts this technique in the preferred tool for lipidomic analyses, which focuses on the complete characterization of lipid species in combination with gene/protein expression under different conditions or aiming at the understanding of turnover and lipid pathways. In this regard, lipidomic approaches, specifically the use of ESI-MS/MS with or without a previous HPLC separation and alternative use of deuterated compounds, permit the thorough characterization of cellular AA dynamics with regard to incorporation into and remodeling between different phospholipid classes, and the liberation of the fatty acid and oygenation to form eicosanoids. Current analysis and characterization of these processes in the context of lipidomics has helped to understand new regulatory features of AA pathways of physiological and pathophysiological relevance. The study of AA regulation along with data from proteomics and genomics will enable the in-depth knowledge of the role of AA in different cell types and patients. This holistic point of view will put AA trafficking and metabolism in the context of systems biology approaches [154].

\section{Acknowledgements}

Work in our laboratory was supported by the Spanish Ministry of Science and Innovation 
(Grants BFU2010-18826 and SAF2010-18831). CIBERDEM is an initiative of Instituto de Salud Carlos III.

\section{References}

[1] T. Yeung, S. Grinstein. Lipid signaling and the modulation of surface charge during phagocytosis. Immunol. Rev. 219 (2007) 17-36.

[2] M. P. Wymann, R. Schneiter. Lipid signalling in disease. Nat. Rev. Mol. Cell Biol. 9 (2008) 162-176.

[3] M. Bou Khalil, W. Hou, H. Zhou, F. Elisma, L. A. Swayne, A. P. Blanchard, Z. Yao, S. A. Bennett, D. Figeys. Lipidomics era: accomplishments and challenges. Mass Spectrom. Rev. 29 (2010) 877-929.

[4] A. M. Hicks, C. J. DeLong, M. J. Thomas, M. Samuel, Z. Cui. Unique molecular signatures of glycerophospholipid species in different rat tissues analyzed by tandem mass spectrometry. Biochim. Biophys. Acta 1761 (2006) 1022-1029.

[5] F. Spener, M. Lagarde, A. Geloen, M. Record. What is lipidomics? Eur. J. Lipid Sci. Technol. 105 (2003) 481-482.

[6] A. D. Watson. Lipidomics: a global approach to lipid analysis in biological systems. J. Lipid Res. 47 (2006) 2101-2111.

[7] M. R. Wenk. Lipidomics: new tools and applications. Cell 143 (2010) 888-895. 
[8] J. B. German, L. A. Gillies, J. T. Smilowitz, A. M. Zivkovic, S. M. Watkins. Lipidomics and lipid profiling in metabolomics. Curr. Opin. Lipidol. 18 (2007) 66-71. [9] E. A. Dennis. Lipidomics joins the omics evolution. Proc. Natl. Acad. Sci. U. S. A. 106 (2009) 2089-2090.

[10] G. van Meer. Cellular lipidomics. EMBO J. 24 (2005) 3159-3165.

[11] M. J. Wakelam, T. R. Pettitt, A. D. Postle. Lipidomic analysis of signaling pathways. Methods Enzymol. 432 (2007) 233-246.

[12] X. Han, R. W. Gross. Global analyses of cellular lipidomes directly from crude extracts of biological samples by ESI mass spectrometry: a bridge to lipidomics. J. Lipid Res. 44 (2003) 1071-1079.

[13] R. Taguchi, T. Houjou, H. Nakanishi, T. Yamazaki, M. Ishida, M. Imagawa, T. Shimizu. Focused lipidomics by tandem mass spectrometry. J. Chromatogr. B Analyt. Technol. Biomed. Life Sci. 823 (2005) 26-36.

[14] X. Han, K. Yang, R. W. Gross, Multi-dimensional mass spectrometry-based shotgun lipidomics and novel strategies for lipidomic analyses, Mass Spectrom. Rev. in press (doi: 10.1002/mas.20342)

[15] O. B. Bleijerveld, M. Houweling, M. J. Thomas, Z. Cui. Metabolipidomics: profiling metabolism of glycerophospholipid species by stable isotopic precursors and tandem mass spectrometry. Anal. Biochem. 352 (2006) 1-14.

[16] H. Sprecher. Metabolism of highly unsaturated n-3 and n-6 fatty acids. Biochim Biophys Acta 1486 (2000) 219-231.

[17] L. Zhou, A. Nilsson. Sources of eicosanoid precursor fatty acid pools in tissues. J Lipid Res 42 (2001) 1521-1542. 
[18] C. D. Funk. Prostaglandins and leukotrienes: advances in eicosanoid biology.

Science 294 (2001) 1871-1875.

[19] J. W. Phillis, L. A. Horrocks, A. A. Farooqui. Cyclooxygenases, lipoxygenases, and epoxygenases in CNS: their role and involvement in neurological disorders. Brain Res. Rev. 52 (2006) 201-243.

[20] Y. Cao, A. T. Pearman, G. A. Zimmerman, T. M. McIntyre, S. M. Prescott. Intracellular unesterified arachidonic acid signals apoptosis. Proc. Natl. Acad. Sci. U.S.A. 97 (2000) 11280-11285.

[21] S. Serini, E. Piccioni, N. Merendino, G. Calviello. Dietary polyunsaturated fatty acids as inducers of apoptosis: implications for cancer. Apoptosis 14 (2009) 135-152. [22] J. Balsinde, R. Pérez, M. A. Balboa. Calcium-independent phospholipase $\mathrm{A}_{2}$ and apoptosis. Biochim. Biophys. Acta 1761 (2006) 1344-1350.

[23] R. Harkewicz, E. Fahy, A. Andreyev, E. A. Dennis. Arachidonate-derived dihomoprostaglandin production observed in endotoxin-stimulated macrophage-like cells. J. Biol. Chem. 282 (2007) 2899-2910.

[24] H. Sprecher, M. VanRollins, F. Sun, A. Wyche, P. Needleman. Dihomoprostaglandins and -thromboxane. A prostaglandin family from adrenic acid that may be preferentially synthesized in the kidney. J. Biol. Chem. 257 (1982) 3912-3918.

[25] M. VanRollins, L. Horrocks, H. Sprecher. Metabolism of 7,10,13,16docosatetraenoic acid to dihomo-thromboxane, 14-hydroxy-7,10,12-nonadecatrienoic acid and hydroxy fatty acids by human platelets. Biochim. Biophys. Acta 833 (1985) $272-280$. 
[26] P. G. Kopf, D. X. Zhang, K. M. Gauthier, K. Nithipatikom, X. Y. Yi, J. R. Falck, W. B. Campbell. Adrenic acid metabolites as endogenous endothelium-derived and zona glomerulosa-derived hyperpolarizing factors. Hypertension 55 (2010) 547-554.

[27] I. Flesch, T. Schonhardt, E. Ferber. Phospholipases and acyltransferases in macrophages. Klin. Wochenschr. 67 (1989) 119-122.

[28] R. F. Irvine. How is the level of free arachidonic acid controlled in mammalian cells? Biochem. J. 204 (1982) 3-16.

[29] F. H. Chilton, A. N. Fonteh, M. E. Surette, M. Triggiani, J. D. Winkler. Control of arachidonate levels within inflammatory cells. Biochim. Biophys. Acta 1299 (1996) 115.

[30] G. Pérez-Chacón, A. M. Astudillo, D. Balgoma, M. A. Balboa, J. Balsinde. Control of free arachidonic acid levels by phospholipases $\mathrm{A}_{2}$ and lysophospholipid acyltransferases. Biochim. Biophys. Acta 1791 (2009) 1103-1113.

[31] J. Balsinde, M. V. Winstead, E. A. Dennis. Phospholipase $A_{2}$ regulation of arachidonic acid mobilization. FEBS Lett 531 (2002) 2-6.

[32] J. Balsinde, M. A. Balboa, P. A. Insel, E. A. Dennis. Regulation and inhibition of phospholipase A2. Annu. Rev. Pharmacol. Toxicol. 39 (1999) 175-189.

[33] C.C. Leslie. Regulation of arachidonic acid availability for eicosanoid production. Biochem. Cell Biol. 82 (2004) 1-17.

[34] J. Balsinde, M. A. Balboa. Cellular regulation and proposed biological functions of group VIA calcium-independent phospholipase $\mathrm{A}_{2}$ in activated cells. Cell. Signal. 17 (2005) 1052-1062. 
[35] M.A. Balboa, J. Balsinde, Oxidative stress and arachidonic acid mobilization. Biochim. Biophys. Acta 1761 (2006) 385-391.

[36] J. Balsinde, B. Fernández, J. A. Solís-Herruzo. Increased incorporation of arachidonic acid into phospholipids in zymosan-stimulated mouse peritoneal macrophages. Eur. J. Biochem. 221 (1994) 1013-1018.

[37] G. Pérez-Chacón, A.M. Astudillo, V. Ruipérez, M.A. Balboa, J. Balsinde. Signaling role for lysophosphatidylcholine acyltransferase 3 in receptor-regulated arachidonic acid reacylation reactions in human monocytes. J. Immunol. 184 (2010) 1071-1078. [38] T. Fujino, M. J. Kang, H. Suzuki, H. Iijima, T. Yamamoto. Molecular characterization and expression of rat acyl-CoA synthetase 3. J. Biol. Chem. 271 (1996) $16748-16752$.

[39] M. J. Kang, T. Fujino, H. Sasano, H. Minekura, N. Yabuki, H. Nagura, H. Iijima, T. T. Yamamoto. A novel arachidonate-preferring acyl-CoA synthetase is present in steroidogenic cells of the rat adrenal, ovary, and testis. Proc. Natl. Acad. Sci. U S A 94 (1997) 2880-2884.

[40] Y. Cao, E. Traer, G. A. Zimmerman, T. M. McIntyre, S. M. Prescott. Cloning, expression, and chromosomal localization of human long-chain fatty acid-CoA ligase 4 (FACL4). Genomics 49 (1998) 327-330.

[41] H. Shindou, M. Eto, R. Morimoto, T. Shimizu. Identification of membrane Oacyltransferase family motifs. Biochem. Biophys. Res. Commun. 383 (2009) 320-325. [42] H. Shindou, D. Hishikawa, H. Nakanishi, T. Harayama, S. Ishii, R. Taguchi, T. Shimizu. A single enzyme catalyzes both platelet-activating factor production and 
membrane biogenesis of inflammatory cells. Cloning and characterization of acetylCoA:Lyso-PAF acetyltransferase. J. Biol. Chem. 282 (2007) 6532-6539.

[43] D. Hishikawa, H. Shindou, S. Kobayashi, H. Nakanishi, R. Taguchi, T. Shimizu. Discovery essential of a lysophospholipid acyltransferase family for membrane asymmetry and diversity. Proc. Natl. Acad. Sci. U. S. A. 105 (2008) 2830-2835.

[44] M. A. Gijón, W. R. Riekhof, S. Zarini, R. C. Murphy, D. R. Voelker. Lysophospholipid acyltransferases and arachidonate recycling in human neutrophils. J. Biol. Chem. 283 (2008) 30235-30245.

[45] Y. Zhao, Y. Q. Chen, T. M. Bonacci, D. S. Bredt, S. Y. Li, W. R. Bensch, D. E. Moller, M. Kowala, R. J. Konrad, G. Q. Cao. Identification and characterization of a major liver lysophosphatidylcholine acyltransferase. J. Biol. Chem. 283 (2008) 82588265.

[46] K. Yuki, H. Shindou, D. Hishikawa, T. Shimizu. Characterization of mouse lysophosphatidic acid acyltransferase 3: an enzyme with dual functions in the testis. J. Lipid Res. 50 (2009) 860-869.

[47] H. C. Lee, T. Inoue, R. Imae, N. Kono, S. Shirae, S. Matsuda, K. Gengyo-Ando, S. Mitani, H. Arai. Caenorhabditis elegans mboa-7, a member of the MBOAT family, is required for selective incorporation of polyunsaturated fatty acids into phosphatidylinositol. Mol. Biol. Cell 19 (2008) 1174-1184.

[48] G. Montero-Morán, J. M. Caviglia, D. McMahon, A. Rothenberg, V. Subramanian, Z. Xu, S. Lara-González, J. Storch, G. M. Carman, D. L. Brasaemle. CGI-58/ABHD5 is a coenzyme A-dependent lysophosphatidic acid acyltransferase. J. Lipid Res 51 (2010) 709-719. 
[49] H. Shindou, D. Hishikawa, T. Harayama, K. Yuki, T. Shimizu. Recent progress on acyl CoA: lysophospholipid acyltransferase research. J. Lipid Res. 50 (2009) S46-S51. [50] H. Shindou, T. Shimizu. Acyl-CoA:lysophospholipid acyltransferases. J. Biol. Chem. 284 (2009) 1-5.

[51] T. Shimizu. Lipid mediators in health and disease: enzymes and receptors as therapeutic targets for the regulation of immunity and inflammation. Annu Rev Pharmacol Toxicol 49 (2009) 123-150.

[52] J. I. MacDonald, H. Sprecher. Phospholipid fatty acid remodeling in mammalian cells. Biochim. Biophys. Acta 1084 (1991) 105-121.

[53] M. Hermansson, K. Hokynar, P. Somerharju. Mechanisms of glycerophospholipid homeostasis in mammalian cells. Prog. Lipid Res. 50 (2011) 240-257.

[54] F. H. Chilton, R. C. Murphy. Remodeling of arachidonate-containing phosphoglycerides within the human neutrophil. J. Biol. Chem 261 (1986) 7771-7777. [55] M. L. Nieto, M. E. Venable, S. A. Bauldry, D. G. Greene, M. Kennedy, D. A. Bass, R. L. Wykle. Evidence that hydrolysis of ethanolamine plasmalogens triggers synthesis of platelet-activating factor via a transacylation reaction. J. Biol. Chem. 266 (1991) 18699-18706.

[56] A. N. Fonteh, F. H. Chilton. Rapid remodeling of arachidonate from phosphatidylcholine to phosphatidylethanolamine pools during mast cell activation. J. Immunol 148 (1992) 1784-1791. [57] J. Balsinde, E. A. Dennis. Distinct roles in signal transduction for each of the

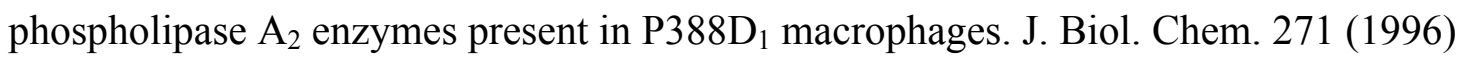
6758-6765. 
[58] E. Boilard, M. E. Surette. (2001) Anti-CD3 and concanavalin A-induced human T cell proliferation is associated with an increased rate of arachidonate-phospholipid remodeling. J. Biol. Chem. 276 (2001) 17568-17575.

[59] J. Balsinde. Roles of various phospholipases $A_{2}$ in providing lysophospholipid acceptors for fatty acid phospholipid incorporation and remodelling. Biochem. J. 364 (2002) 695-702.

[60] J. D. Winkler, C. M. Sung, C. F. Bennett, F. H. Chilton. Characterization of CoAindependent transacylase activity in U937 cells. Biochim. Biophys. Acta 1081 (1991) $339-346$

[61] A. M. Astudillo, G. Pérez-Chacón, D. Balgoma, L. Gil-de-Gómez, V. Ruipérez, C. Guijas, M. A. Balboa, J. Balsinde. Influence of cellular arachidonic acid levels on phospholipid remodeling and CoA-independent transacylase activity in human monocytes and U937 cells. Biochim. Biophys. Acta 1811 (2011) 97-103

[62] J. E. Burke, E. A. Dennis. Phospholipase $\mathrm{A}_{2}$ structure/function, mechanism, and signaling. J. Lipid Res 50 (2009) S237-S242.

[63] R. H. Schaloske, E. A. Dennis. The phospholipase $A_{2}$ superfamily and its group numbering system. Biochim. Biophys. Acta 1761 (2006) 1246-1259.

[64] D. A. Six, E. A. Dennis. The expanding superfamily of phospholipase $\mathrm{A}_{2}$ enzymes: classification and characterization. Biochim. Biophys. Acta 1488 (2000) 1-19. [65] M. Murakami, Y. Taketomi, Y. Miki, H. Sato, T. Hirabayashi, K. Yamamoto. Recent progress in phospholipase $A_{2}$ research: from cells to animals to humans. Prog. Lipid Res 50 (2011) 152-192. 
[66] Z. H. Qiu, M. A. Gijón, M. S. de Carvalho, D. M. Spencer, C. C. Leslie. The role of calcium and phosphorylation of cytosolic phospholipase $\mathrm{A}_{2}$ in regulating arachidonic acid release in macrophages. J. Biol. Chem. 273 (1998) 8203-8211.

[67] H. Fujishima, R. O. Sanchez Mejia, C. O. Bingham, B. K. Lam, A. Sapirstein, J. V. Bonventre, K. F. Austen, J. P. Arm. Cytosolic phospholipase $A_{2}$ is essential for both the immediate and the delayed phases of eicosanoid generation in mouse bone marrowderived mast cells. Proc. Natl. Acad. Sci. U.S.A. 96 (1999) 4803-4807.

[68] J. Balsinde, M.A. Balboa, P.A. Insel, E.A. Dennis, Differential regulation of phospholipase $\mathrm{D}$ and phospholipase $\mathrm{A}_{2}$ by protein kinase $\mathrm{C}$ in $\mathrm{P} 388 \mathrm{D}_{1}$ macrophages, Biochem. J. 321 (1997) 805-809.

[69] M. Murakami, T. Kambe, S. Shimbara, K. Higashino, K. Hanasaki, H. Arita, M. Horiguchi, M. Arita, H. Arai, K. Inoue, I. Kudo, Different functional aspects of the group II subfamily (types IIA and V) and type $\mathrm{X}$ secretory phospholipase $\mathrm{A}_{2} \mathrm{~s}$ in regulating arachidonic acid release and prostaglandin generation, J. Biol. Chem. 274 (1999) 3143531444.

[70] H. Shinohara, M.A. Balboa, C.A. Johnson, J. Balsinde, E.A. Dennis, Regulation of delayed prostaglandin production in activated $\mathrm{P} 388 \mathrm{D}_{1}$ macrophages by group IV cytosolic and group V secretory phospholipase $\mathrm{A}_{2} \mathrm{~s}$, J. Biol. Chem. 274 (1999) 1226312268.

[71] J. Balsinde, M.A. Balboa, S. Yedgar, E.A. Dennis, Group V phospholipase $\mathrm{A}_{2^{-}}$ mediated oleic acid mobilization in lipopolysaccharide-stimulated $\mathrm{P}_{388 \mathrm{D}_{1}}$ macrophages, J. Biol. Chem. 275 (2000) 4783-4786. 
[72] J. Marshall, E. Krump, T. Lindsay, G. Downey, D. A. Ford, P. Zhu, P. Walker, B. Rubin. Involvement of cytosolic phospholipase $\mathrm{A}_{2}$ and secretory phospholipase $\mathrm{A}_{2}$ in arachidonic acid release from human neutrophils. J. Immunol. 164 (2000) 2084-2091. [73] J. Balsinde, M.A. Balboa, E.A. Dennis, Identification of a third pathway for arachidonic acid mobilization and prostaglandin production in activated $\mathrm{P} 388 \mathrm{D}_{1}$ macrophage-like cells, J. Biol. Chem. 275 (2000) 22544-22549.

[74] M. A. Gijón, D. M. Spencer, A. R. Siddiqi, J. V. Bonventre, C. C. Leslie CC. Cytosolic phospholipase $A_{2}$ is required for macrophage arachidonic acid release by agonists that do and do not mobilize calcium. Novel role of mitogen-activated protein kinase pathways in cytosolic phospholipase $\mathrm{A}_{2}$ regulation. J. Biol. Chem. 275 (2000) 20146-20156.

[75] M. Murakami, R.S. Koduri, A. Enomoto, S. Shimbara, M. Seki, K. Yoshihara, A. Singer, E. Valentin, F. Ghomashchi, G. Lambeau, M.H. Gelb, I. Kudo, Distinct arachidonate-releasing functions of mammalian secreted phospholipase $\mathrm{A}_{2} \mathrm{~S}$ in human embryonic kidney 293 and rat mastocytoma RBL-2H3 cells through heparan sulfate shuttling and external plasma membrane mechanisms, J. Biol. Chem. 276 (2001) 1008310096.

[76] M.A. Balboa, R. Pérez, J. Balsinde, Amplification mechanisms of inflammation: paracrine stimulation of arachidonic acid mobilization by secreted phospholipase $A_{2}$ is regulated by cytosolic phospholipase $\mathrm{A}_{2}$-derived hydroperoxyeicosatetraenoic acid, J. Immunol. 171 (2003) 989-994. 
[77] M.A. Balboa, Y. Shirai, G. Gaietta, M.H. Ellisman, J. Balsinde, E.A. Dennis, Localization of group $\mathrm{V}$ phospholipase $\mathrm{A}_{2}$ in caveolin-enriched granules in activated P388D 1 macrophage-like cells, J. Biol. Chem. 278 (2003) 48059-48065.

[78] Y. Satake, B.L. Díaz, B. Balestrieri, B.K. Lam, Y. Kanaoka, M.J. Grusby, J.P. Arm, Role of group $\mathrm{V}$ phospholipase $\mathrm{A}_{2}$ in zymosan-induced eicosanoid generation and vascular permeability revealed by targeted gene disruption, J. Biol. Chem. 279 (2004) $16488-16494$.

[79] C. Mounier, F. Ghomashchi, M.R. Lindsay, S. James, A.G. Singer, R.G. Parton, M.H. Gelb, Arachidonic acid release from mammalian cells transfected with human groups IIA and $\mathrm{X}$ secreted phospholipase $\mathrm{A}_{2}$ predominantly during the secretory process and with the involvement of cytosolic phospholipase $\mathrm{A}_{2} \alpha$, J. Biol. Chem. 279 (2004) $25024-25038$.

[80] Y. Shirai, J. Balsinde, E.A. Dennis, Localization and functional interrelationships among cytosolic group IV, secreted group $\mathrm{V}$, and $\mathrm{Ca}^{2+}$-independent group VI

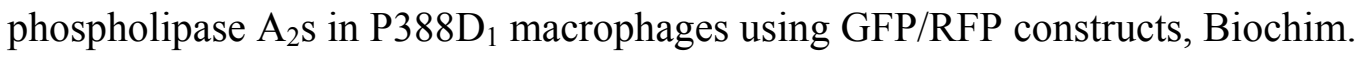
Biophys. Acta 1735 (2005) 119-129.

[81] H. Kuwata, T. Nonaka, M. Murakami, I. Kudo, Search of factors that intermediate cytokine-induced group IIA phospholipase $\mathrm{A}_{2}$ expression through the cytosolic phospholipase $\mathrm{A}_{2}$-and 12/15-lipoxygenase-dependent pathway, J. Biol. Chem. 280 (2005) $25830-25839$.

[82] J. Casas, M.A. Gijón, A.G. Vigo, M.S. Crespo, J. Balsinde, M.A. Balboa, Phosphatidylinositol 4,5-bisphosphate anchors cytosolic group IVA phospholipase $\mathrm{A}_{2}$ to 
perinuclear membranes and decreases its calcium requirement for translocation in live cells, Mol. Biol. Cell 17 (2006) 155-162.

[83] G.T. Wijewickrama, J.H. Kim, Y.J. Kim, A. Abraham, Y. Oh, B. Ananthanarayanan, M. Kwatia, S.J. Ackerman, W. Cho, Systematic evaluation of transcellular activities of secretory phospholipases $A_{2}$. High activity of group $V$ phospholipase $A_{2}$ to induce eicosanoid biosynthesis in neighboring inflammatory cells, J. Biol. Chem. 281 (2006) $10935-10944$.

[84] B.L. Diaz, Y. Satake, E. Kikawada, B. Balestrieri, J.P. Arm, Group V secretory phospholipase $A_{2}$ amplifies the induction of cyclooxygenase 2 and delayed prostaglandin $\mathrm{D}_{2}$ generation in mouse bone marrow culture-derived mast cells in a strain-dependent manner, Biochim. Biophys. Acta 1761 (2006) 1489-1497.

[85] J. Pindado, J. Balsinde, M. A. Balboa. TLR3-dependent induction of nitric oxide synthase in RAW 264.7 macrophage-like cells via a cytosolic phospholipase $\mathrm{A}_{2}$ /cyclooxygenase-2 pathway. J. Immunol. 179 (2007) 4821-4828.

[86] E. Kikawada, J.V. Bonventre, J.P. Arm, Group V secretory PLA2 regulates TLR2dependent eicosanoid generation in mouse mast cells through amplification of ERK and cPLA $_{2} \alpha$ activation, Blood 110 (2007) 561-567.

[87] V. Ruipérez, J. Casas, M.A. Balboa, J. Balsinde, Group V phospholipase A2-derived $_{2}$ lysophosphatidylcholine mediates cyclooxygenase-2 induction in lipopolysaccharidestimulated macrophages, J. Immunol. 179 (2007) 631-638.

[88] V. Ruipérez, A.M. Astudillo, M.A. Balboa, J. Balsinde, Coordinate regulation of Toll-like receptor-mediated arachidonic acid mobilization in macrophages by group IVA and group V phospholipase A2s, J. Immunol. 182 (2009) 3877-3883. 
[89] S. Suram, T. A. Gangelhoff, P. R. Taylor, M. Rosas, G. D. Brown, J. V. Bonventre, S. Akira, S. Uematsu, D. L. Williams, R. C. Murphy, C. C. Leslie. Pathways regulating cytosolic phospholipase $A_{2}$ activation and eicosanoid production in macrophages by Candida albicans. J. Biol. Chem. 285 (2010) 30676-30685.

[90] K. J. Bryant, M. J. Bidgood, P. W. Lei, M. Taberner, C. Salom, V. Kumar, L. Lee, W. B. Church, B. Courtenay, B. P. Smart, M. H. Gelb, M. A. Cahill, G. G. Graham, H. P. McNeil, K. F. Scott. A bifunctional role for group IIA secreted phospholipase $A_{2}$ in human rheumatoid fibroblast-like synoviocyte arachidonic acid metabolism. J Biol Chem 286 (2011) 2492-2503.

[91] W. K. Han, A. Sapirstein, C. C. Hung, A. Alessandrini, and J. V. Bonventre. Cross-

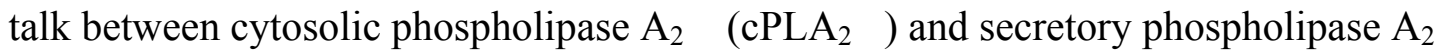
$\left(\mathrm{SPLA}_{2}\right)$ in hydrogen peroxide-induced arachidonic acid release in murine mesangial cells: $\mathrm{sPLA}_{2}$ regulates $\mathrm{cPLA}_{2}$ activity that is responsible for arachidonic acid release. $\mathrm{J}$ Biol Chem 278 (2003) 24153-24163.

[92] D. M. Nikolic, M. C. Gong, J. Turk, J., S. R. Post, Class A scavenger receptormediated macrophage adhesion requires coupling of calcium-independent phospholipase $\mathrm{A}_{2}$ and 12/15-lipoxygenase to Rac and Cdc42 activation. J. Biol. Chem. 282 (2007) 33405-33411.

[93] M.A. Balboa, J. Balsinde, Involvement of calcium-independent phospholipase $A_{2}$ in hydrogen peroxide-induced accumulation of free fatty acids in human U937 cells, J. Biol. Chem. 277 (2002) 40384-40389. 
[94] C. R. Yellaturu, G. N. Rao, A requirement for calcium-independent phospholipase $\mathrm{A}_{2}$ in thrombin-induced arachidonic acid release and growth in vascular smooth muscle cells. J. Biol. Chem. 278 (2003) 43831-43837.

[95] J. Balsinde, M. A. Balboa, E. A. Dennis. Antisense inhibition of group VI Ca ${ }^{2+}-$ independent phospholipase $\mathrm{A}_{2}$ blocks phospholipid fatty acid remodeling in murine P388D 1 macrophages. J. Biol. Chem. 272 (1997) 29317-29321.

[96] R. Pérez, R. Melero, M. A. Balboa, and J. Balsinde. Role of group VIA calciumindependent phospholipase $\mathrm{A}_{2}$ in arachidonic acid release, phospholipid fatty acid incorporation, and apoptosis in U937 cells responding to hydrogen peroxide. J. Biol. Chem 279 (2004) 40385-40391.

[97] R. Pérez, X. Matabosch, A. Llebaria, M. A. Balboa, J. Balsinde. Blockade of arachidonic acid incorporation into phospholipids induces apoptosis in U937 promonocytic cells. J. Lipid Res. 47 (2006) 484-491. [98] M. V. Winstead, J. Balsinde, and E. A. Dennis. Calcium-independent phospholipase $\mathrm{A}_{2}$ : structure and function. Biochim. Biophys. Acta 1488 (2000) 28-39.

[99] M. Ghosh, D. E. Tucker, S. A. Burchett, and C. C. Leslie. Properties of the group IV phospholipase $\mathrm{A}_{2}$ family. Prog. Lipid Res 45 (2006) 487-510.

[100] G. Lambeau and M. H. Gelb. Biochemistry and physiology of mammalian secreted phospholipases A2. Annu. Rev. Biochem 77 (2008) 495-520.

[101] C. C. Leslie. Regulation of the specific release of arachidonic acid by cytosolic phospholipase $A_{2}$. Prostaglandins Leukot. Essent. Fatty Acids 70 (2004) 373-376. 
[102] T. Hirabayashi, T. Murayama, and T. Shimizu. Regulatory mechanism and physiological role of cytosolic phospholipase A2. Biol. Pharm. Bull 27 (2004) 11681173.

[103] J. V. Bonventre and A. Sapirstein. Group IV cytosolic phospholipase $A_{2}$ function: insights from the knockout mouse. Adv Exp Med Biol 507 (2002) 25-31.

[104] E. A. Dennis, J. Cao, Y. H. Hsu, V. Magriotti, and G. Kokotos, Phospholipase A2 enzymes: physical structure, biological function, disease implication, chemical inhibition, and therapeutic intervention. Chem. Rev. in press (DOI: 10.1021/cr200085w).

[105] M. W. Buczynski, D. S. Dumlao, and E. A. Dennis. An integrated omics analysis of eicosanoid biology. J. Lipid Res 50 (2009) 1015-1038.

[106] M. J. Stables and D. W. Gilroy. Old and new generation lipid mediators in acute inflammation and resolution. Prog. Lipid Res. 50 (2011) 35-51.

[107] B. Samuelsson, S. E. Dahlen, J. A. Lindgren, C. A. Rouzer, and C. N. Serhan. Leukotrienes and lipoxins - structures, biosynthesis, and biological effects. Science 237 (1987) 1171-1176.

[108] S. Feltenmark, N. Gautam, A. Brunnström, W. Griffiths, L. Backman, C. Edenius, L. Lindbom, M. Björkholm, H. E. Claesson, Eoxins are proinflammatory arachidonic acid metabolites produced via the 15-lipoxygenase-1 pathway in human eosinophils and mast cells. Proc. Natl. Acad. Sci. U.S.A. 105 (2008) 680-685.

[109] G. Fredman, C. N. Serhan, Specialized proresolving mediator targets for RvE1 and RvD1 in peripheral blood and mechanisms of resolution. Biochem. J. 437 (2011) 185197. 
[110] D. Sacerdoti, A. Gatta, J. C. McGiff. Role of cytochrome P450-dependent arachidonic acid metabolites in liver physiology and pathophysiology. Prostaglandins Other Lipid Mediat 72 (2003) 51-71.

[111] A. A. Spector, X. Fang, G. D. Snyder, N. L. Weintraub, Epoxyeicosatrienoic acids (EETs): metabolism and biochemical function. Prog Lipid Res.43 (2004) 55-90.

[112] U. Jahn, J. M. Galano, T. Durand, Beyond prostaglandins - Chemistry and biology of cyclic oxygenated metabolites formed by free radical pathways from polyunsaturated fatty acids. Angew Chem. Int. Ed. 47 (2008), 5894-5955.

[113] E. Diez, J. Balsinde, M. Aracil, A. Schüller, Ethanol induces release of arachidonic acid but not synthesis of eicosanoids in mouse peritoneal macrophages, Biochim. Biophys. Acta 921 (1987) 82-89.

[114] J. Balsinde, B. Fernández, J.A. Solís-Herruzo, Pathways for arachidonic acid mobilization in zymosan-stimulated mouse peritoneal macrophages, Biochim. Biophys. Acta $1136(1992) 75-82$.

[115] J. Balsinde, B. Fernández, E. Diez E, Regulation of arachidonic acid release in mouse peritoneal macrophages. The role of extracellular calcium and protein kinase $\mathrm{C}, \mathrm{J}$. Immunol. 144 (1990) 4298-4304.

[116] J. Balsinde, S. E. Barbour, I. D. Bianco, E. A. Dennis. Arachidonic acid mobilization in $\mathrm{P}_{388} \mathrm{D}_{1}$ macrophages is controlled by two distinct $\mathrm{Ca}^{2+}$-dependent phospholipase $A_{2}$ enzymes. Proc. Natl. Acad. Sci. U.S.A. 91 (1994) 11060-11064. [117] J. Balsinde, M. A. Balboa MA, E. A. Dennis, Inflammatory activation of arachidonic acid signaling in murine $\mathrm{P}_{388} \mathrm{D}_{1}$ macrophages via sphingomyelin synthesis. J. Biol. Chem. 272 (1997) 20373-20377. 
[118] J. Balsinde, M. A. Balboa, and E. A. Dennis. Functional coupling between secretory phospholipase $A_{2}$ and cyclooxygenase- 2 and its regulation by cytosolic group IV phospholipase A2. Proc. Natl. Acad. Sci. U.S.A. 95 (1998) 7951-7956.

[119] M.A. Balboa, Y. Sáez, J. Balsinde, Calcium-independent phospholipase $\mathrm{A}_{2}$ is required for lysozyme secretion in U937 promonocytes, J. Immunol. 170 (2003) 52765280.

[120] F. H. Chilton, R. C. Murphy, Stimulated production and natural occurrence of 1,2diarachidonoylglycerophosphocholine in human neutrophils, Biochem. Biophys. Res. Commun 145 (1987) 1126-1133.

[121] F. H. Chilton, J. S. Hadley, R. C. Murphy, Incorporation of arachidonic acid into 1acyl-2-lyso-sn-glycero-3-phosphocholine of the human neutrophil, Biochim. Biophys. Acta 917 (1987) 48-56.

[122] F. H. Chilton, T. R. Connell, 1-ether-linked phosphoglycerides, Major endogenous sources of arachidonate in the human neutrophil, J. Biol. Chem. 263 (1988) 5260-5265. [123] H. W. Mueller, J. T. O'Flaherty, D. G. Greene, M. P. Samuel, R. L. Wykle, 1-Oalkyl-linked glycerophospholipids of human neutrophils: distribution of arachidonate and other acyl residues in the ether-linked and diacyl species, J. Lipid Res. 25 (1984) 383388.

[124] T. Sugiura, O. Katayama, J. Fukui, Y. Nakagawa, K. Waku, Mobilization of arachidonic acid between diacyl and ether phospholipids in rabbit alveolar macrophages, FEBS Lett. 165 (1984) 273-276.

[125] R. C. Murphy, J. Fiedler, J. Hevko, Analysis of nonvolatile lipids by mass spectrometry. Chem. Rev. 101 (2001) 479-526. 
[126] M. Pulfer, R. C. Murphy. Electrospray mass spectrometry of phospholipids. Mass Spectrom. Rev. 22 (2003) 332-364.

[127] X. Han, R. W. Gross. Shotgun lipidomics: electrospray ionization mass spectrometric analysis and quantitation of cellular lipidomes directly from crude extracts of biological samples. Mass Spectrom. Rev. 24 (2005) 367-412.

[128] L. D. Roberts, G. McCombie, C. M. Titman, J. L. Griffin, A matter of fat: an introduction to lipidomic profiling methods. J. Chromatogr. B Analyt. Technol. Biomed. Life Sci. 871 (2008) 174-181.

[129] T. M. Annesley, Ion suppression in mass spectrometry. Clin. Chem. 49 (2003) 1041-1044.

[130] M. Stahlman, C. S. Ejsing, K. Tarasov, J. Perman, J. Boren, K. Ekroos, Highthroughput shotgun lipidomics by quadrupole time-of-flight mass spectrometry. J. Chromatogr. B Analyt. Technol. Biomed. Life Sci. 877 (2009) 2664-2672.

[131] C. S. Ejsing, T. Moehring, U. Bahr, E. Duchoslav, M. Karas, K. Simons, A. Shevchenko, Collision-induced dissociation pathways of yeast sphingolipids and their molecular profiling in total lipid extracts: a study by quadrupole TOF and linear ion traporbitrap mass spectrometry. J. Mass Spectrom. 41 (2006) 372-389.

[132] A. Larsen, S. Uran, P. B. Jacobsen, T. Skotland, Collision-induced dissociation of glycero phospholipids using electrospray ion-trap mass spectrometry. Rapid Commun. Mass. Spectrom. 15 (2001) 2393-2398.

[133] K. Ekroos, C. S. Ejsing, U. Bahr, M. Karas, K. Simons, A. Shevchenko, Charting molecular composition of phosphatidylcholines by fatty acid scanning and ion trap MS3 fragmentation. J. Lipid Res. 44 (2003) 2181-2192. 
[134] Z. Cui, M. J. Thomas, Phospholipid profiling by tandem mass spectrometry. J. Chromatogr. B Analyt. Technol. Biomed. Life Sci. 877 (2009) 2709-2715.

[135] C. S. Ejsing, E. Duchoslav, J. Sampaio, K. Simons, R. Bonner, C. Thiele, K.

Ekroos, A. Shevchenko, Automated identification and quantification of glycerophospholipid molecular species by multiple precursor ion scanning. Anal. Chem. 78 (2006) 6202-6214.

[136] D. Balgoma, O. Montero, M. A. Balboa, J. Balsinde. Lipidomic approaches to the study of phospholipase $\mathrm{A}_{2}$-regulated phospholipid fatty acid incorporation and remodeling. Biochimie 92 (2010) 645-650.

[137] E. Vernooij, J. Brouwers, J. J. Kettenes-van den Bosch, D. J. A. Crommelin, RPHPLC/ESI MS determination of acyl chain positions in phospholipids. J. Sep. Sci. 25 (2002) 285-289.

[138] F. F. Hsu, J. Turk, Electrospray ionization with low-energy collisionally activated dissociation tandem mass spectrometry of glycerophospholipids: mechanisms of fragmentation and structural characterization. J. Chromatogr. B Analyt. Technol. Biomed. Life Sci. 877 (2009) 2673-2695.

[139] R. Harkewicz, E. A. Dennis, Applications of mass spectrometry to lipids and membranes. Annu. Rev. Biochem. 80 (2011) 301-325.

[140] R.C. Murphy, P. H. Axelsen, Mass spectrometric analysis of long-chain lipids, Mass Spectrom. Rev. 30 (2011) 579-599.

[141] A. D. Postle, A. N. Hunt, Dynamic lipidomics with stable isotope labelling. J. Chromatogr. B Analyt. Technol. Biomed. Life Sci, 877 (2009) 2716-2721. 
[142] D. Balgoma, O. Montero, M. A. Balboa, J. Balsinde, Calcium-independent phospholipase $\mathrm{A}_{2}$-mediated formation of 1,2-diarachidonoyl-glycerophosphoinositol in monocytes, FEBS J. 275 (2008) 6180-6191.

[143] C. A. Rouzer, P. T. Ivanova, M. O. Byrne, S. B. Milne, L. J. Marnett, H. A. Brown, Lipid profiling reveals arachidonate deficiency in RAW264.7 cells: structural and functional implications, Biochemistry 45 (2006) 14795-14808.

[144] C. A. Rouzer, P. T. Ivanova, M. O. Byrne, H. A. Brown, L. J. Marnett, Lipid profiling reveals glycerophospholipid remodeling in zymosan-stimulated macrophages, Biochemistry 46 (2007) 6026-6042.

[145] D. Balgoma, A. M. Astudillo, G. Pérez-Chacón, O. Montero, M. A. Balboa, J. Balsinde, Markers of monocyte activation revealed by lipidomic profiling of arachidonic acid-containing phospholipids, J. Immunol. 184 (2010) 3857-3865.

[146] X. Han, R. A. Gubitosi-Klug, B. Collins, R. W. Gross, Alterations in individual molecular species of human platelet phospholipids during thrombin stimulation: electrospray ionization mass spectrometry-facilitated identification of the boundary conditions for the magnitude and selectivity of thrombin-induced platelet phospholipid hydrolysis, Biochemistry 35 (1996) 5822-5832.

[147] M. Valdearcos, E. Esquinas, C. Meana, L. Gil de Gómez, C. Guijas, J. Balsinde, M. A. Balboa, Subcellular localization and role of lipin-1 in human macrophages, J. Immunol. 186 (2011) 6004-6013. [148] A. M. Astudillo, G. Pérez-Chacón, C. Meana, D. Balgoma, A. Pol, M. A. del Pozo, M. A. Balboa, J. Balsinde, Altered arachidonate distribution in macrophages from 
caveolin-1 null mice leading to reduced eicosanoid synthesis, J. Biol. Chem. 286 (2011) 35299-35307.

[149] P. T. Ivanova, S. B. Milne, H. A. Brown, Identification of atypical ether-linked glycerophospholipid species in macrophages by mass spectrometry, J. Lipid Res. 51 (2010) 1581-1590.

[150] J. Yang, S. Yang, X. Gao, Y. J. Yuan, Integrative investigation of lipidome and signal pathways in human endothelial cells under oxidative stress, Mol. Biosyst. (2011) DOI: $10.1039 / \mathrm{c} 1 \mathrm{mb} 00002 \mathrm{k}$.

[151] E. A. Dennis, R. A. Deems, R. Harkewicz, O. Quehenberger, H. A. Brown, S. B. Milne, D. S. Myers, C. K. Glass, G. Hardiman, D. Reichart, A. H. Merrill, Jr., M. C. Sullards, E. Wang, R. C. Murphy, C. R. Raetz, T. A. Garrett, Z. Guan, A. C. Ryan, D. W. Russell, J. G. McDonald, B. M. Thompson, W. A. Shaw, M. Sud, Y. Zhao, S. Gupta, M. R. Maurya, E. Fahy, S. Subramanian, A mouse macrophage lipidome, J. Biol. Chem. 285 (2010) 39976-39985.

[152] P. C. Norris, D. Reichart, D. S. Dumlao, C. K. Glass, E. A. Dennis, Specificity of eicosanoid production depends on the TLR-4-stimulated macrophage phenotype. J. Leukoc. Biol. (2011) doi: 10.1189/jlb.0311153 jlb.0311153.

[153] A. Y. Andreyev, E. Fahy, Z. Guan, S. Kelly, X. Li, J. G. McDonald, S. Milne, D. Myers, H. Park, A. Ryan, B. M. Thompson, E. Wang, Y. Zhao, H. A. Brown, A. H. Merrill, C. R. Raetz, D. W. Russell, S. Subramaniam, E. A. Dennis, Subcellular organelle lipidomics in TLR-4-activated macrophages, J. Lipid Res. 51 (2010) 2785-2797.

[154] H. A. Brown and R. C. Murphy. Working towards an exegesis for lipids in biology. Nat. Chem. Biol. 5 (2009) 602-606. 
[155] E. Fahy, S. Subramaniam, H. A. Brown, C. K. Glass, A. H. Merrill, Jr., R. C.

Murphy, C. R. Raetz, D. W. Russell, Y. Seyama, W. Shaw, T. Shimizu, F. Spener, G. van Meer, M. S. Van Nieuwenhze, S. H. White, J. L. Witztum, and E. A. Dennis, A comprehensive classification system for lipids. J. Lipid Res. 46 (2005) 839-861. 


\section{Figure Legends}

Figure 1. AA incorporation in glycerophospholipids. AA is obtained directly from diet or synthesized from linoleic acid. Afterward, AA is incorporated into the sn-2 position of glycerophospholipids and later subjected to remodeling processes via CoA-IT-dependent reactions. ACS: acyl:CoA synthetase; LPCAT: lysophosphatidylcholine:acyl-CoA acyltransferase; PLA $\mathrm{A}_{2}$ : phospholipase $\mathrm{A}_{2}$; CoA-IT: independent-CoA transacylase.

Figure 2. The four pathways for AA metabolism into eicosanoids four different pathways; cyclooxygenase, lipoxygenase, cytochrome-P450 and non-enzymatic oxidation reactions.

Figure 3. AA-containing PC, PE and PI species in human monocytes (blue), human monocyte-derived macrophages (red) and mouse peritoneal macrophages (green). Data represent means of three independent determinations (S.E.M. $<15 \%$ for all determinations), and are given as a percent with respect to the total amount of AAcontaining phospholipids. For further details see text. Shorthand notation of glycerophospholipids (abscissa) follows the guidelines proposed by Fahy et al. [155]. 


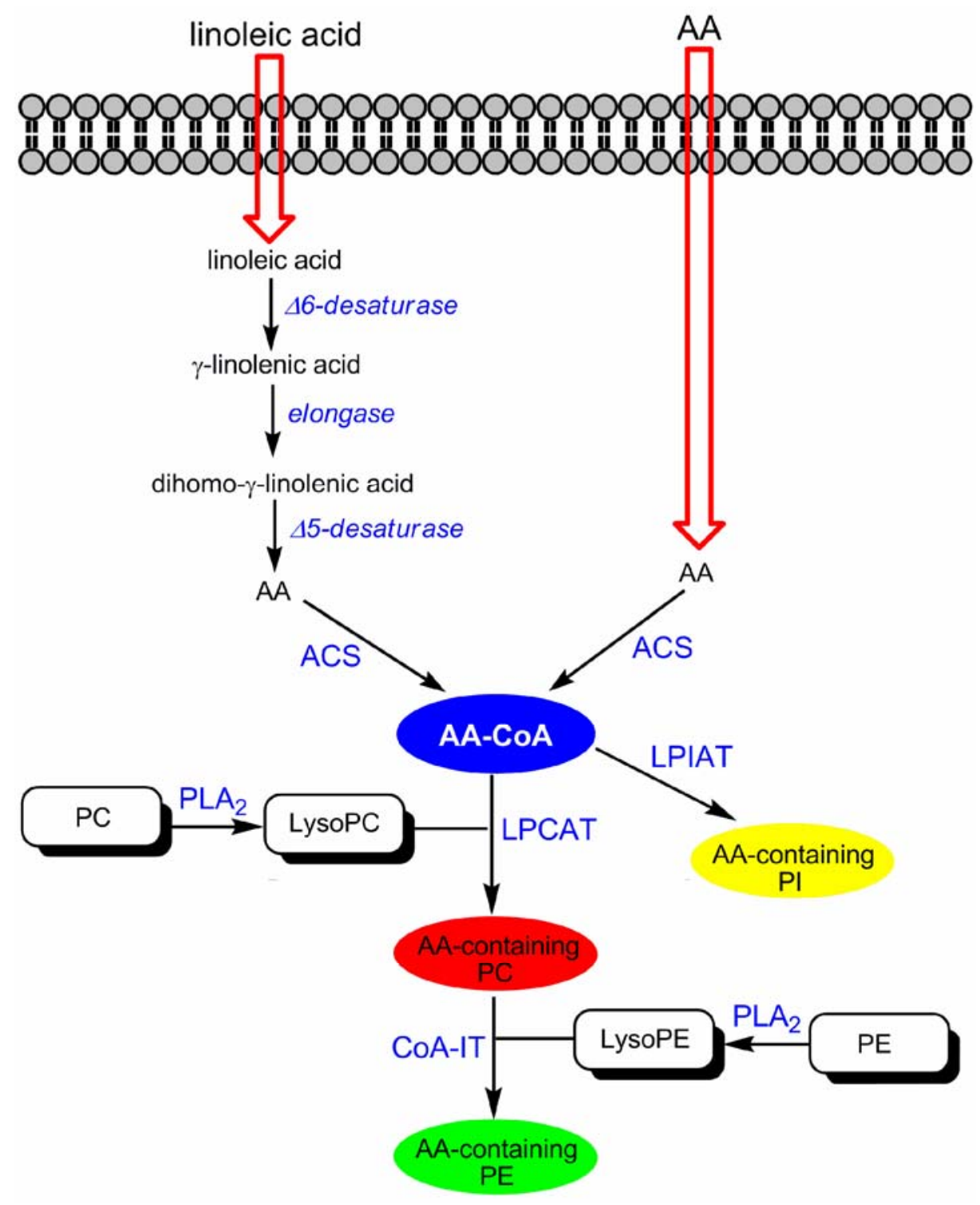

Figure 1 


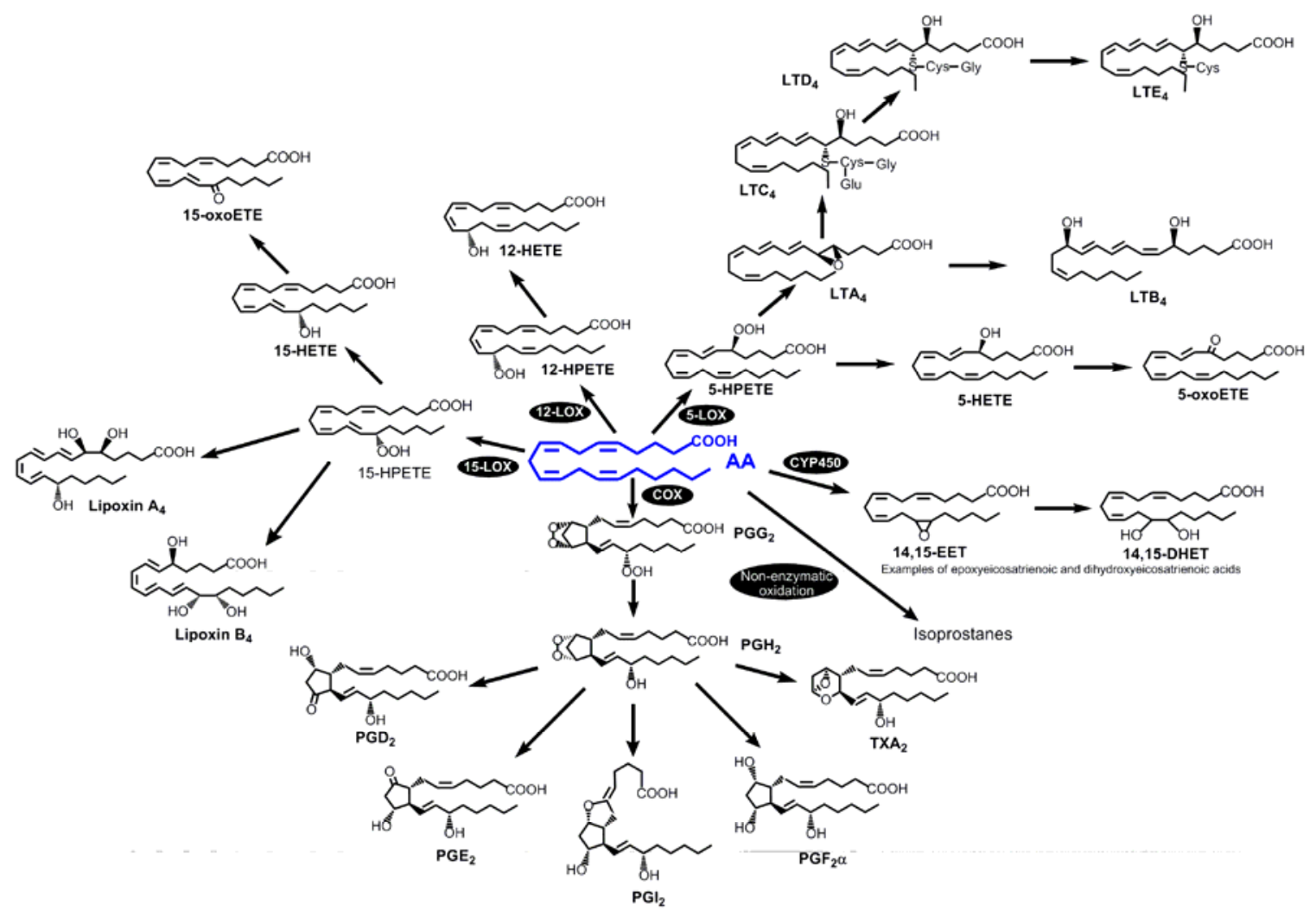

Figure 2 


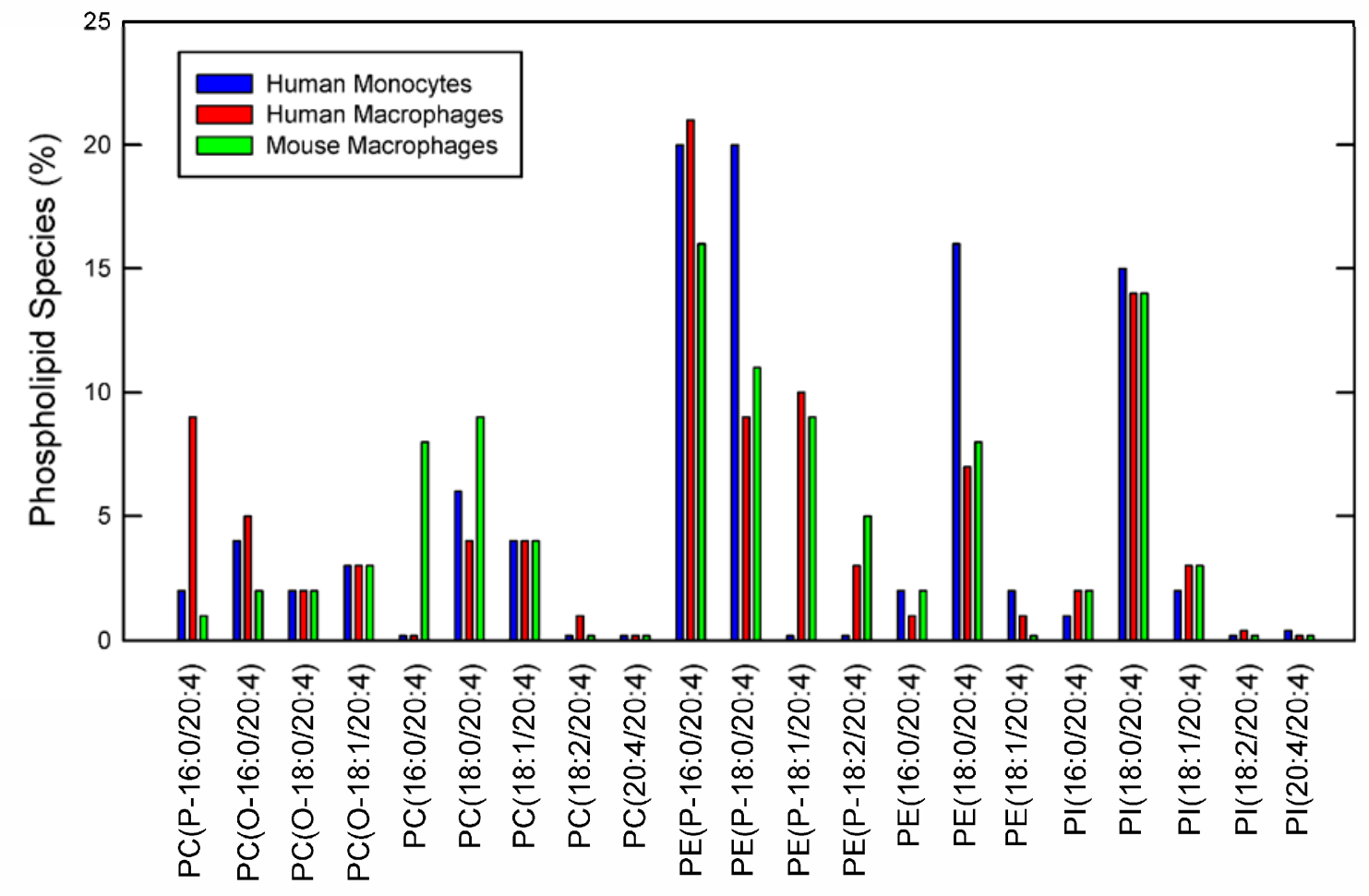

Figure 3 